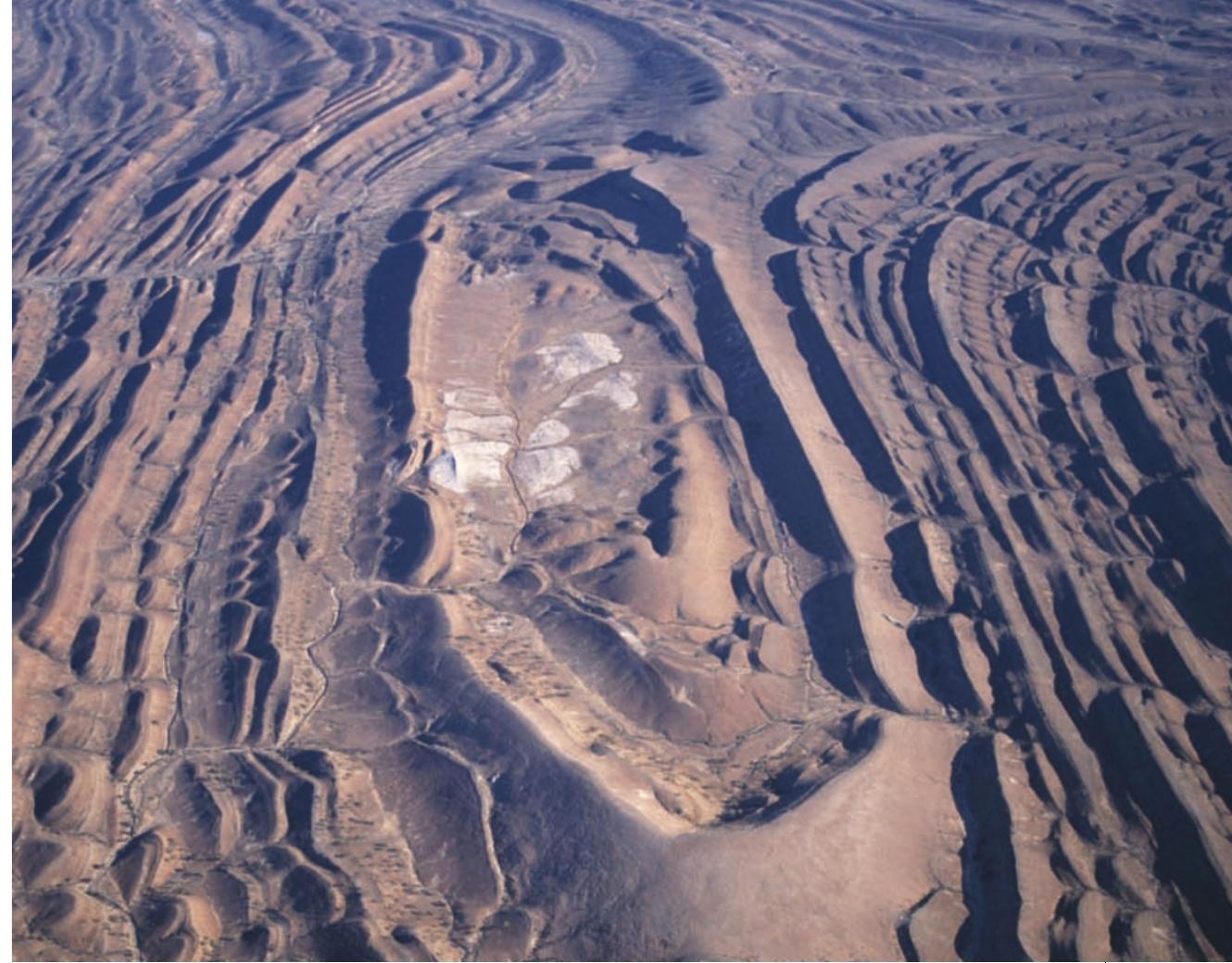

sions of our planet's timeline are prone to change. Geologists argue over what defines the boundaries between these periods, and disagree over exactly how old they are. The end of the Jurassic period, for instance, has wobbled by more than 30 million years since it was dated in the 1930s (refs 1,2).

This summer, the first fully revised geological timescale for 15 years will be published ${ }^{3}$, helping to clear up some of the confusion. The new scale will help Earth scientists speak to one another in a common language, and the dates will help to answer questions about what caused various mass extinctions and changes in climate. The project will even have an impact on oil companies, which base their exploration programmes in part on estimates of the age of rocks.

The timescale (see below) has been a long time in the making. "I thought it would take two years," says one of its editors, James Ogg of Purdue University in West Lafayette, Indiana. Instead it took seven. Ogg is also secretary-general of the International Commission on Stratigraphy (ICS), the organization that coordinated the project.

But despite being the most complete work on dates so far - and the first to be endorsed by the ICS's parent body, the

Rock of ages: geologists are using Australia's Flinders Ranges to define a Precambrian period.

International Union of Geological Sciences (IUGS) - the new timescale is not definitive. Its assembly has rekindled a long-standing debate on how to define the earliest geological time periods, and many of those boundaries look set to change in the next few years. And as the dates are re-examined, the timescale may even widen to encompass rocks beyond Earth.

\section{Event horizons}

Over the past 150 years, geologists have struggled to unravel Earth's history. To a large extent, they have relied on significant events, such as the appearance of a specific fossil, or a reversal in the planet's magnetic field, to define the boundary between two time periods. Having defined these physical boundaries, researchers then attempted to date them. But geologists in different parts of the world used different rocks as benchmarks, leading to disagreements over the exact definition of each period.

To resolve the issue, stratigraphers are deploying 'golden spikes' - also known as global standard stratotype-section and points
(GSSPs). These are locations where a good example of a worldwide event can be found, nominated by working groups within the ICS and then ratified by the IUGS. Once a spike is set, that rock remains the boundary of a time period, even if estimates of its age change.

The first GSSP was established in 1972 near the town of Klonk, in what is now the Czech Republic. Here can be found pristine fossils of an extinct marine invertebrate called a graptolite, the appearance of which divides the Silurian from the Devonian ${ }^{4}$. But the spike system was slow to catch on. For the 1989 timescale, fewer than 15 out of the 91 geological stage boundaries between now and the beginning of the Cambrian period had been marked with golden spikes.

In 1999, the IUGS executive called for a concerted effort to find GSSPs ${ }^{5}$, and the past few years have seen a surge of activity. Political as well as scientific arguments ensued. In the debate over where to put the spike separating the Permian from the Triassic, the relative inaccessibility of sites in Kashmir and Iran helped to rule them out in favour of one in Zhejiang Province, China. For Chinese

\title{
Phanerozoje eOd]
}


stratigraphers, this was the equivalent of winning a bid to host the Olympics. They hoisted a six-metre-tall monument on the spot to commemorate the achievement.

The spike count now stands at 50. But finding GSSPs is only half the battle - the divisions need dates too. The new timescale takes advantage of a growing ability to date rocks using astronomical events, says Felix Gradstein of the University of Oslo, Norway, ICS chairman and another of the timescale's editors. Using this technique, the past 23 million years - the Neogene period - has been dated to within plus or minus 40,000 years ${ }^{3}$. "This is the single most exciting scientific development in the new timescale," says Gradstein. "Every geologist should be amazed by this."

\section{The dating game}

Astronomical dating back-calculates cycles in Earth's orbit to work out its climate. This is then matched to climate records in the rocks: variations in the ratios of different oxygen isotopes reflect the size of the polar ice caps at the time the rock was laid down, and calcium carbonate content reflects the sea's temperature, for example ${ }^{6}$. The chaotic nature of orbital cycles means that, for now, this method is accurate only to about 65 million years ago. But researchers are confident that it will soon extend back 150 million years.

To pin down the age of older rocks, geologists rely on radiometric dating, which tracks the radioactive decay of elements within a sample. But in the past decade, it has become clear that the results from different techniques and different labs don't agree.

The changing age of the Jurassic is a case in point. In 1987, the period was estimated to have ended 131 million years ago, based on the amount of potassium that had been converted into argon in a mineral called glauconite ${ }^{2}$. But it was later discovered that argon seeps out of glauconite, making the mineral seem younger than it actually is. The new timescale used potassium-argon dating of basalt to put the end of the Jurassic at 145.5 million years ago.

"Most people will tell you that a measurement more than five years old is obsolete," says Gradstein. The inconsistencies highlighted by the timescale's construction prompted researchers to propose an international network of laboratories, all using a standard procedure, to which anyone could send a rock sample for dating ${ }^{7}$. These labs should begin publishing results in about a year.

Uncertainty over dates is a particular problem for the early life of Earth. When these time periods were established, it was thought that there would be too few benchmarks to define GSSPs: rocks get

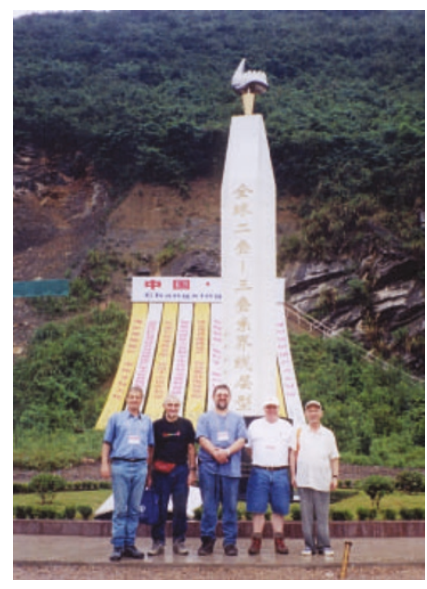

Geologists stand by the Chinese monument that marks a 'golden spike' between two ages. common language. The Moon's birth, in a collision between Earth and another planet-sized body about 4.5 billion years ago, would be a good candidate for a spike, he argues, marking the beginning of the Hadean eon - a name that is not yet official, but which many geologists use to describe the time before the Archaean. Using this as a spike would synchronize the terrestrial timescale with the lunar, which currently has its own periods. "On the Moon, there are many obvious stratigraphic boundaries that rarer as they get older, and there are no large fossils from that long ago. Instead, each period is anchored by round dates rather than golden spikes. Most of the Precambrian, the first four billion years of Earth's history, is chopped up in this way.

Some Earth scientists have railed against this system ever since the ICS decided on it in the 1980s, complaining that it is inconsistent. "There's been a ferocious debate between a bunch of field-based mavericks and the committees," says geologist Euan Nisbet of Royal Holloway, a college of the University of London in Egham.

It now looks as if the argument is going the mavericks' way. In March this year, the first golden spike was driven into Precambrian time - rocks in Australia's Flinders Ranges that record the end of glaciations thought to have covered Earth some 600 million years ago have become the starting point for the Ediacaran.

More ancient spikes are set to come. The new chairman of the ICS Precambrian subcommission, Wouter Bleeker of the Geological Survey of Canada, Ottawa, is on a mission to use rock features to divide up the deep past. Ultimately, Bleeker hopes that the geological record can be extended through space to cover the entire Solar System, giving geologists and planetary scientists a probably have relevance on Earth," says Bleeker. "It's very important to try to synchronize where we can."

To define such ancient spikes, geologists will need to relax their criteria. There is no worldwide record of the Ediacaran changes seen in Australia, and this will be true for other spikes in the distant past. Nevertheless, Bleeker hopes to have a broad framework of Precambrian spikes worked out by 2008 . "We're probably going to move towards using the rock record to divide the Precambrian," agrees Ogg.

By 2008, all of the geological time divisions in the past 600 million years should also bear golden spikes. Good news for geologists seeking to speak a common language; but more work for Gradstein and his team. "We should have a second edition then," he says.

\section{John Whitfield is a science writer based in London.}

1. Holmes, A. The Age of The Earth (Nelson, London, 1937).

2 Haq, B. U., Hardenbol, J. \& Vail, P. R. Science 235, 1156-1167 (1987).

3. Gradstein, F. M., Ogg, J. G. \& Smith, A. G. (eds) A Geologic Time Scale 2004 (Cambridge Univ. Press, in the press).

4. Chlupác, I. \& Kukal, Z. in The Silurian-Devonian Boundary (ed. Martinsson, A.) IUGS Ser. A, Vol. 5, 96-109 (IUGS, Stuttgart, 1977).

5. Vai, G. B. Episodes 24, 29-31 (2001).

6. Hilgen, F. J., Krijgsman, W., Langereis, C. G. \& Lourens, L. J. Eos 78, 285, 288-289 (1997).

. Clarke, T. Nature 425, 550-551 (2003).

\section{www.stratigraphy.org}

\section{Proterozoje end]}
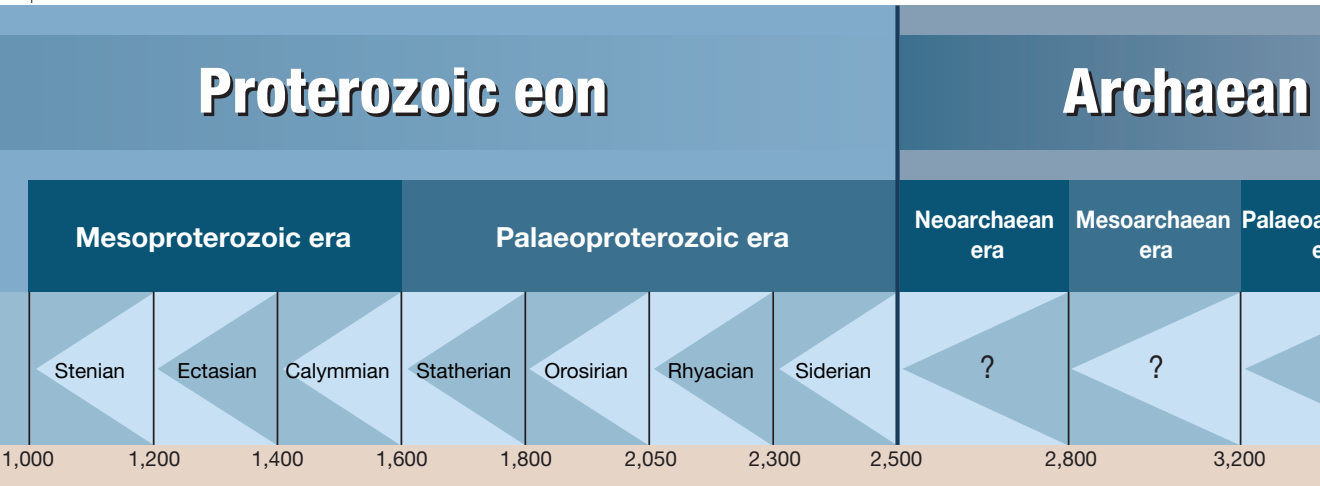

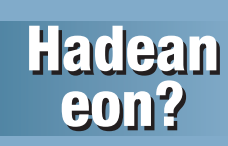

